\title{
Irrigation management of a peach orchard
}

\author{
Nagy, A. ${ }^{1}$, Riczu, P. ${ }^{1}$, Tamás, J. ${ }^{1}$, Szabó, Z. ${ }^{2}$, Nyéki, J. ${ }^{2}$ \& Soltész, M. ${ }^{3}$ \\ ${ }^{1}$ University of Debrecen, Centre of Agricultural Sciences and Engineering, Faculty of Agricultural and Food \\ Sciences and Environmental Management, Institute of Water and Environmental Management, \\ H-4032 Debrecen, Böszörményi 138, Hungary, attilanagy@agr.unideb.hu \\ ${ }^{2}$ University of Debrecen, Institute for Research and Development, H-4032 Debrecen, Böszörményi 138, Hungary \\ ${ }^{3}$ Collage of Kecskemét, Faculty of Horticulture, H-6000 Erdei Ferenc tér 1-3.
}

\begin{abstract}
Summary: The research field was at Siófok, in Hungary, which is situated in the South East side of Lake Balaton. The physical characteristic of the soil is sandy loam and loam and the peach orchard is irrigated. Mainly Sweet Lady (early ripening), Red Heaven (medium ripening) és Veinberger (early ripening) species were installed. In order to achieve the optimal developement level of trees and maximal yield amount and fruit diameter (Sweet Lady 60-75 mm, Red Heaven 60-70 mm, Veinberger 50-60 mm) continous water and nutrient supply is required. The irrigation modeling was set by CROPWAT 8.0 based on the climatic, crop and soil data inputs of the last 10 years. Based on the results, large amount of water is needed for optimal growth of fruit trees, particularly in the summer months, in case of active ground cover $(+)$ and bare soil (-) as well. The irrigation requirement of a tree was found maximum 4 1/hour in certain cases. This irrigation intensity can be achieved calculated with 12-hour operating time - by using continuous water NAAN Tif drip tube with 2 1/h flux on 3 atm pressure with 16 mm pipe diameter. If lower irrigation intensity is required irrigation can be controlled by the decreased the operation time.
\end{abstract}

Key words: drip irrigation, peach orchard, CROPWAT model

\section{Introduction}

It can be forecast with high probability that in future water will be the determining (hopefully not limiting) factor of food security and environmental safety in the Carpathian Basin (Somlyódy, 2000; Várallyay, 2002). The extremities in the amount and distribution of rain are showing an increasing tendency in Hungary (Várallyay, 2005), which often causes problems in crop production.

Since the water resources are limited in time and in space, significant part of the orchard owners are using - if they can afford it - water supplement watering. Because the actual water cycle of the fruit orchards are not exactly known, the impact of this watering is occasional. Accurate irrigation scheduling is needed to match the depth of application to the crop water requirement. Proper irrigation scheduling requires actual crop water use data in relation to the potential water use (evapotranspiration) as a function of plant development (Ayars et al. 2003). Drip irrigation spread in the orchards is due to the $90-95 \%$ of water use efficiency (Tóth, 1995). The drip irrigation is good delivery system because it allows doing the agricultural procedures between the rows in the orchards and providing the water and nutrient used by fertigation to reach the high density root zone.

Peach fruit development occurs in three phases. In the first phase, fruit size increases primarily due to cell division. During the second "pit hardening" phase, there is little increase in fruit size. The third phase from pit hardening to harvest is marked by rapid fruit growth which results from cell expansion. This third phase cell expansion requires ample available water, and occurs during the hottest and driest summer conditions (Black et al, 2008). Post harvest irrigation is also hardly recommended for facilitating the root growth and tree health status. Although peach can not tolerate high ground water level, but requires $5000-7500 \mathrm{~m}^{3}$ water per a hectare (500-750 mm) (Papp, 2003) at tree spacing of 4. $\times$ $6 \mathrm{~m}$ (417 trees/hectares) this comes to 12 to $18 \mathrm{~m}^{3}$ of water per tree of orchard. In peach, optimal productivity is experienced with rain or irrigation at intervals of no longer than one week. During peak water use periods, individual peach trees consume 130-150 liters' per tree per day.

\section{Materials and methods}

The research field was at Siófok, in Hungary, which is situated in the South East side of Lake Balaton. The physical characteristic of the soil is sandy loam and loam and the peach orchard is irrigated. Mainly Sweet Lady (late ripening), Red Heaven (mid ripening) és Veinberger (early ripening) species were installed. In order to achieve the optimal developement level of trees and maximal yield amount and fruit diameter (Sweet Lady 60-75 mm, Red Heaven 60-70 mm, Veinberger 50-60 mm) continous water and nutrient supply is required.

The irrigation modeling was set by CROPWAT 8.0 based on the climatic, crop and soil data inputs of the last 10 years. Special attention was taken on 2009 , because of the long 
term drought. Climatic data and rain fall data was obtained from the meteorological station next to the orchard. One of the key role of irrigation is the proper determination of evapotranspiration. Using the calculation of water balance regime evapotranspiration can be determined indirectly with the following equation, based on FAO 56 (Allen et al. 1998):

$$
\mathrm{ET}_{\mathrm{c}, \mathrm{i}}=\mathrm{D}_{\mathrm{r}, \mathrm{i}}-\mathrm{D}_{\mathrm{r}, \mathrm{i}-1}+(\mathrm{P}-\mathrm{RO})_{\mathrm{i}}+\mathrm{I}_{\mathrm{i}}+\mathrm{CR}_{\mathrm{i}}-\mathrm{DP}_{\mathrm{i}}
$$

where

$\mathrm{ET}_{\mathrm{c}, \mathrm{i}}$ crop evapotranspiration on day i [mm],

$\mathrm{D}_{\mathrm{r}, \mathrm{i}}$ root zone depletion at the end of day $\mathrm{i}[\mathrm{mm}]$,

$\mathrm{D}_{\mathrm{r}, \mathrm{i}-1}$ water content in the root zone at the end of the previous day, i-1 [mm],

$\mathrm{P}_{\mathrm{i}} \quad$ precipitation on day $\mathrm{i}[\mathrm{mm}]$,

$\mathrm{RO}_{\mathrm{i}}$ runoff from the soil surface on day i [mm],

$\mathrm{I}_{\mathrm{i}}$ net irrigation depth on day $\mathrm{i}$ that infiltrates the soil [mm],

$\mathrm{CR}_{\mathrm{i}}$ capillary rise from the groundwater table on day $\mathrm{i}$ [mm],

$\mathrm{DP}_{\mathrm{i}} \quad$ water loss out of the root zone by deep percolation on day i $[\mathrm{mm}]$.

Crop and fruit evapotranspiration can also be calculated from climatic data and by integrating directly the crop or fruit resistance, albedo and air resistance factors in the Penman-Monteith approach, i.e., ET $\mathrm{ET}_{\mathrm{o}}$ As there is a considerable lack of information for different crops or fruits the Penman-Monteith method is used for the estimation of the standard reference crop or fruit to determine its evapotranspiration rate. From the original Penman-Monteith equation and the equations of the aerodynamic and surface resistance, the FAO 56 Penman-Monteith method to estimate $\mathrm{ET}_{\mathrm{o}}$ is expressed as:

$$
E T_{0}=\frac{0.408 \Delta\left(R_{n}-G\right)+\gamma \frac{900}{T+273} u_{2}\left(e_{s}-e_{a}\right)}{\Delta+\gamma\left(1+0.34 u_{2}\right)}
$$

where:

$\mathrm{ET}_{\mathrm{O}}$ reference evapotranspiration $\left[\mathrm{mm} \mathrm{day}^{-1}\right]$,

$\mathrm{R}_{\mathrm{n}} \quad$ net radiation at the crop surface $\left[\mathrm{MJ} \mathrm{m}^{-2}\right.$ day $\left.^{-1}\right]$,

$\mathrm{G} \quad$ soil heat flux density $\left[\mathrm{MJ} \mathrm{m}^{-2}\right.$ day $\left.^{-1}\right]$,

$\mathrm{T}$ mean daily air temperature at $2 \mathrm{~m}$ height $\left[{ }^{\circ} \mathrm{C}\right]$,

$\mathrm{u}_{2} \quad$ wind speed at $2 \mathrm{~m}$ height $\left[\mathrm{m} \mathrm{s}^{-1}\right]$,

$\mathrm{e}_{\mathrm{s}} \quad$ saturation vapour pressure $[\mathrm{kPa}]$,

$\mathrm{e}_{\mathrm{a}} \quad$ actual vapour pressure $[\mathrm{kPa}]$,

$\mathrm{e}_{\mathrm{s}} \quad$ - ea saturation vapour pressure deficit $[\mathrm{kPa}]$,

D slope vapour pressure curve $\left[\mathrm{kPa}^{\circ} \mathrm{C}^{-1}\right]$,

$\gamma \quad$ psychrometric constant $\left[\mathrm{kPa}^{\circ} \mathrm{C}^{-1}\right]$.

Differences in leaf anatomy, stomatal characteristics, aerodynamic properties and even albedo cause the crop or fruit evapotranspiration to differ from the reference crop or fruit evapotranspiration under the same climatic conditions. Due to variations in the crop, and in fruits as well, characteristics throughout its growing season, $\mathrm{K}_{\mathrm{c}}$ for a given crop or fruit changes from sowing till harvest. In the crop coefficient approach the crop or fruit evapotranspiration, $\mathrm{ET}_{\mathrm{c}}$, is calculated by multiplying the reference crop or fruit evapotranspiration, $\mathrm{ET}_{\mathrm{o}}$, by a crop coefficient, $\mathrm{K}_{\mathrm{c}}$ :

$$
\mathrm{ET}_{\mathrm{c}}=\mathrm{K}_{\mathrm{c}} * \mathrm{ET}_{\mathrm{o}}
$$

where

$\mathrm{ET}_{\mathrm{c}}$ crop evapotranspiration $\left[\mathrm{mm} \mathrm{d}^{-1}\right]$,

$\mathrm{K}_{\mathrm{c}} \quad$ crop coefficient [dimensionless],

$\mathrm{ET}_{\mathrm{o}}$ reference crop evapotranspiration $\left[\mathrm{mm} \mathrm{d}^{-1}\right]$.

Crop coefficient is computed for the following crop growing stages:

- initial stage,

- crop development stage,

- mid-season,

- late season.

However, row spacings are grassed in the peach orchard, crop coefficients, based on the recommendation of Irrigation and Drainage FAO 56 paper, were set both for ground cover and bare surface. The reason for this is that flat sites with lower than 5\% steepness and very low erosion risks do not require any grassed cover, thus the amount of irrigation can be reduced.

Since the value of the actual crop water requirement based on model sensitivity analyses depends on the actual value of $\mathrm{K}_{\mathrm{c}}$ significantly, the error propagation influences the reliability of the whole model. One of the aims of our further researches is the rise of the accuracy of this parameter using remote sensing data source.

Besides evapotranspiration, the amount of precipitation also determines the amount or irrigation water. However, the efficiency of the total precipitation is never $100 \%$, therefore the effective rain should be calculated. All rainfall options refer to the calculation of the effective rainfall based on the actual rainfall data. The options are:

Fixed percentage: The fixed percentage is to be given by the user to account for the losses due to runoff and deep percolation. Effective rainfall is a fixed percentage of actual rainfall.

Dependable rainfall (FAO/AGLW formula): Based on an analysis carried out for different arid and sub-humid climates, an empirical formula was developed in the Water Service of FAO to estimate dependable rainfall, the combined effect of dependable rainfall (80\% probability of exceedance) and estimated losses due to Runoff (RO) and Deep Percolation (DP). This formula may be used for design purposes where $80 \%$ probability of exceedance is required. Calculation according to (monthly step):

$$
\begin{gathered}
\mathrm{P}_{\text {eff }}=0.6 * \mathrm{P}-10 \text { for } \mathrm{P}_{\text {month }}<=70 \mathrm{~mm} ; \\
\mathrm{P}_{\text {eff }}=0.8 * \mathrm{P}-24 \text { for } \mathrm{P}_{\text {month }}>70 \mathrm{~mm}
\end{gathered}
$$

Empirical formula: Same formula as for Dependable rainfall but with the possibility to change the parameters, 
which may be determined from an analysis of local climatic records (monthly step):

$$
\begin{gathered}
\mathrm{P}_{\text {eff }}=\mathrm{a} * \mathrm{P}_{\text {month }}-\mathrm{b} \text { for } \mathrm{P}_{\text {month }}<=\mathrm{z} \mathrm{mm} ; \\
\mathrm{P}_{\text {eff }}=\mathrm{c} * \mathrm{P}_{\text {month }}-\mathrm{d} \text { for } \mathrm{P}_{\text {month }}>\mathrm{z} \mathrm{mm}
\end{gathered}
$$

values for $\mathrm{a}, \mathrm{b}, \mathrm{c}, \mathrm{d}$ and $\mathrm{z}$ are correlation coefficients.

USDA Soil Conservation Service: Formula developed by USCS, where effective rainfall can be calculated according to (monthly step):

$$
\begin{gathered}
\mathrm{P}_{\text {eff }}=\mathrm{P}_{\text {month }} *\left(125-0.2 * \mathrm{P}_{\text {month }}\right) / 125 \text { for } \mathrm{P}_{\text {month }}<=250 \mathrm{~mm} \\
\mathrm{P}_{\text {eff }}=125+0.1 * \mathrm{P}_{\text {month }} \text { for } \mathrm{P}_{\text {month }}>250 \mathrm{~mm}
\end{gathered}
$$

The Sweet Lady on GF-677 rootstock has 1,2 m maximum, $0,8-1 \mathrm{~m}$ average rooting depth, Red Heaven on wild peach rootstock has maximum $1,2 \mathrm{~m}$ root depth on sandy loam soil with low ground water level, although the active absorption zone is between $0,3-0,7 \mathrm{~m}$ in case of irrigated conditions. The available soil moisture content is evaluated in the ratio of Total Available Water (TAW) in the CROPWAT 8.0 software. The irrigation of different peach varieties were adjusted with different initial soil water depletion values. In the case of Sweet Lady variety the initial soil water depletion value was 30\%, in case of Red Heaven it was $40 \%$ and in case of Veinberger it was $20 \%$. The nearly 40 -year-old database of local meteorological station was used to analyze the climate conditions. The year of 2003 was droughty, which is very interesting from irrigation point of view.

\section{Results and discussion}

\section{Meteorological data}

The meteorological database shows, that the climatic conditions of the investigated area are optimal for peach production (Figure 1). Based on this, the average precipitation $(557 \mathrm{~mm})$ is close to the national average in Siófok, but its distribution is more favorable compared to the dryer Hungarian Great Plan.

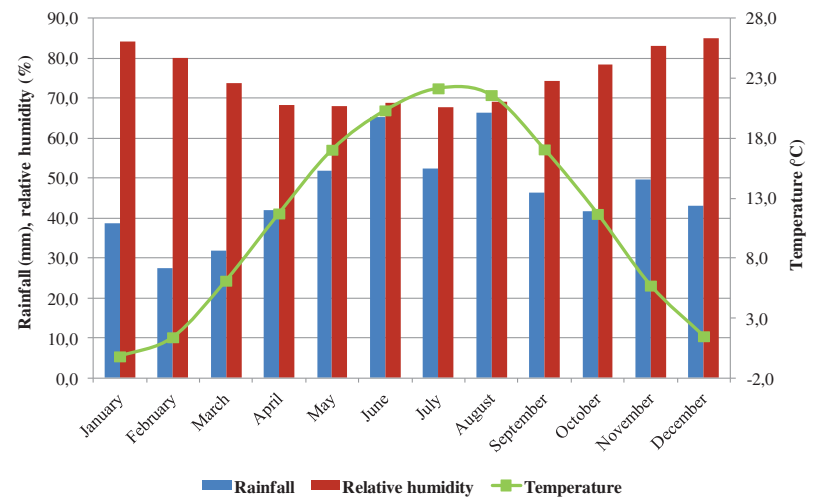

Figure 1. Climatic conditions based on the 38-year-old climatic database
In certain years, rainfall is differ from the average and this alteration could influence the productivity of the orchard (Figure 2). There was a drier period in April both in years of 2007 and 2008, which was compensated the rainfall of June, but at end of the summer evolved a another precipitation deficit. The drip irrigation system is suitable for providing the appropriate yield quantity and quality.

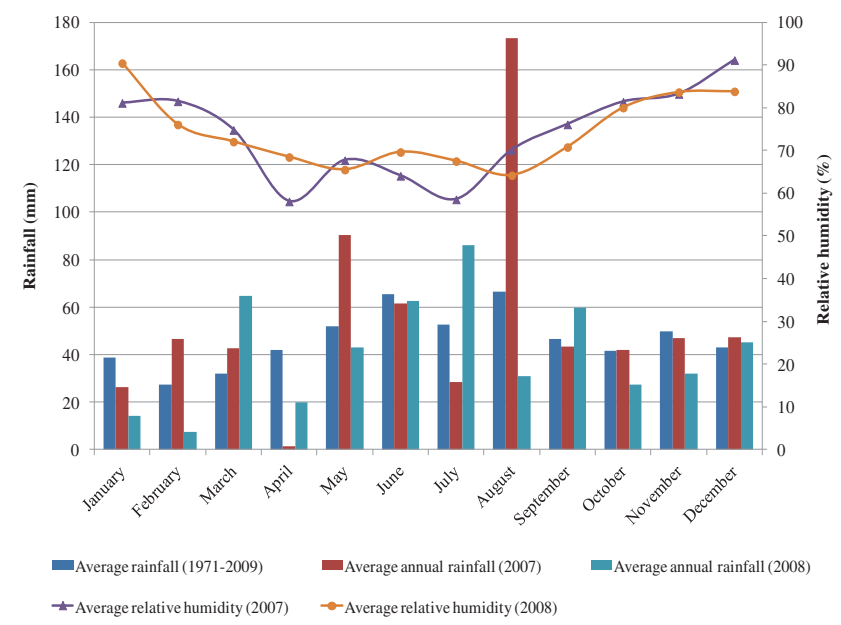

Figure 2. Precipitation and relative humidity in the years of 2007 and 2008

Beside the operation of drip irrigation system it is recommended to establish an irrigation system for frost protection, since spring frost could cause severe damages in a peach orchard in certain years. As an example, in March of 2003 there were 13 freezing days, while in March of 2005 there were 15 days below zero Celsius degree.

\section{Irrigation management researches}

The determination of evapotranspiration has the greatest uncertainty out of all agro-hydrological elements. There are some methods to calculate the potential evapotranspiration. In the case of modeling, the FAO Penman-Monteith method was used.

The driest (2003: $395 \mathrm{~mm}$ ) year of the last decade has been taken into account to define the required irrigation of the orchard. The required irrigation of the late-ripening Sweet Lady, the mid-ripening Red Heaven and the earlyripening Veinberger peach varieties were calculated, considering the soil type (sandy loam) and soil conditions too. Based on the results of, large amount of water is needed for optimal growth of fruit trees, particularly in the summer months, in case of active ground cover (+) and bare soil (-) as well (Figure 3-5). Some factors which has to be concerned in the modeling process influence adversely the utilization of rainfall. The most important factors are the following: evaporation, deep infiltration, surface runoff. The related effects can varies in space and time, thus several methods became widespread. The effective rainfall was calculated in the driest (2003) year in the CROPWAT. The effective rainfall refers to that portion of rainfall that can effectively be 
used by plants. The effective rainfall values were $154.7 \mathrm{~mm}$ with the USDA method, $85.7 \mathrm{~mm}$ with the "dependable rain" (FAO) method and $133 \mathrm{~mm}$ with the empirical formula in case of Sweet Lady variety. The FAO method and the empirical formula are appropriate in arid climate condition, but the USDA method is ideal for the wetter humid climate conditions, so we used this method for the irrigation scheduled.

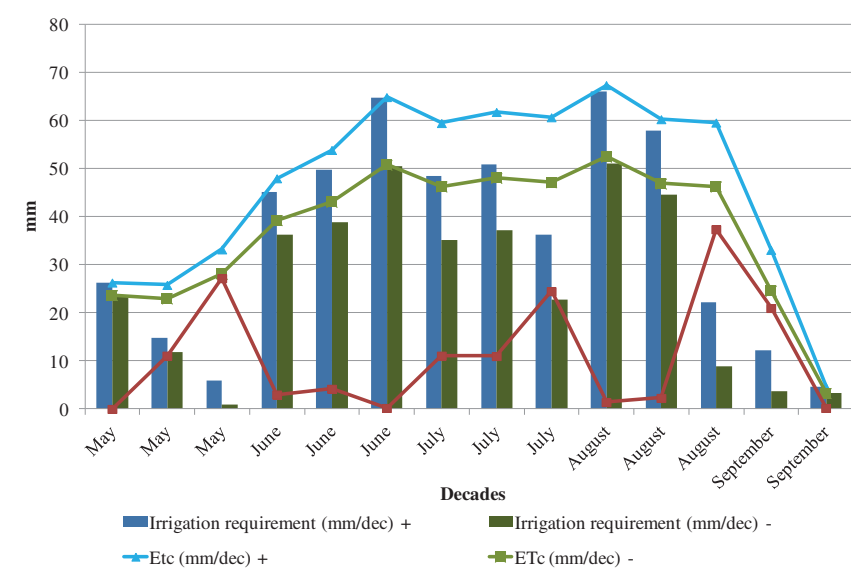

Figure 3. Irrigation requirement and evapotranspiration of Sweet Lady in 2003 (+: with active ground cover, -: bare soil)

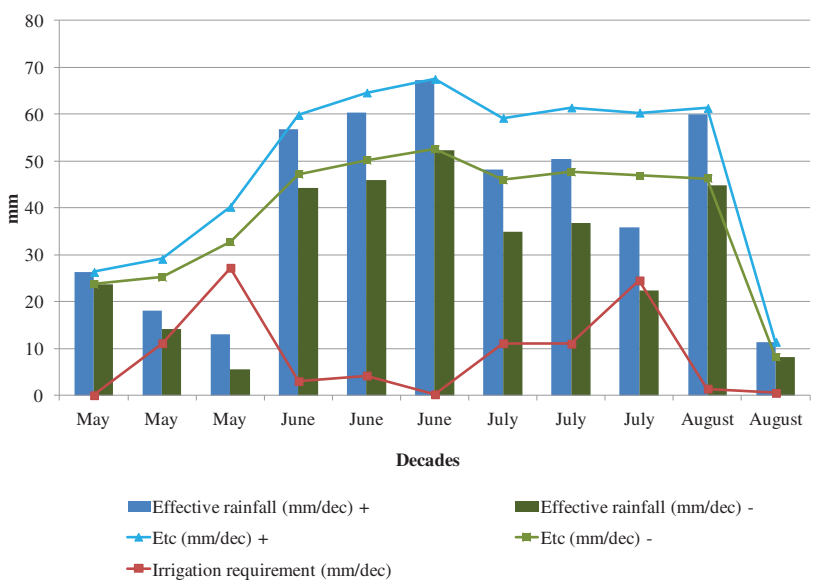

Figure 4. Irrigation requirement and evapotranspiration of Red Haeven in 2003 (+: with active ground cover, -: bare soil)

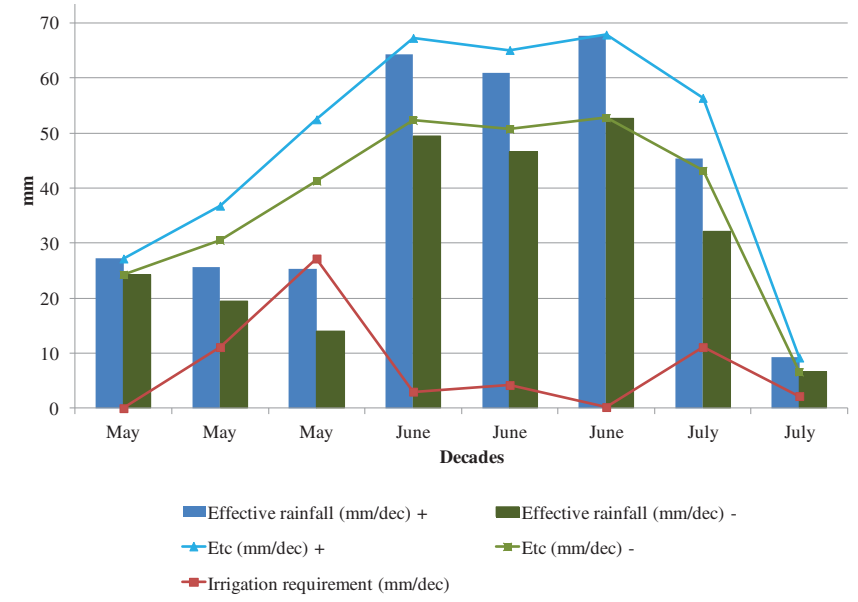

Figure 5. Irrigation requirement and evapotranspiration of Veinberger in 2003 (+: with active ground cover, -: bare soil)
The irrigation requirements of the three species were modeled considering the water requirement of the varieties in case of active ground cover and bare soil too. The driest (2003) year was chosen for irrigation planning to ensure yield safety and the appropriate quality and quantity yield. Based on the 38-year-old meteorological database, the water demand is $80-500 \mathrm{~mm}$ for the irrigation with $3-12$ irrigation turns. The irrigation requirement is about $390 \mathrm{~mm}$ in an average year with 6-7 irrigation turns.

The irrigation requirement (1/s/ha) can be calculated out of the gross irrigation need $(\mathrm{mm})$ and from the rooting depth. This represents the continuous water demand of the orchard during an irrigation turn. Gross irrigation represents the water depth (in $\mathrm{mm}$ ) applied on the field. The irrigation efficiency is never $100 \%$, since only a part of gross irrigation could be utilized. The net irrigation represents the water depth (expressed in $\mathrm{mm}$ ) that can be used by the orchard. The water loss of drip irrigation system is minimal, thus the efficiency was set $95 \%$ in the model. The irrigation requirement of a tree was expressed in liter/tree/hour with 12 hours operating time and $24 \mathrm{~m}^{2} /$ tree space $(6 \mathrm{~m}$ row spacing, $4 \mathrm{~m}$ plant-to-plant distance).

Out of the examined peach species Sweet Lady requires the highest amount of water. Considering that the water moisture content is $50-60 \%$ of the field capacity, the irrigation turns were planned in case of $30 \%$ depletion. As an example, Table 1. shows the Sweet Lady irrigation turns in the driest year, in case of active ground cover and bare soil.

The irrigation requirement of a tree was found maximum $41 /$ hour in certain cases. This irrigation intensity can be achieved - calculated with 12-hour operating time - by using continuous water NAAN Tif drip tube with 2 1/h flux on 3 atm pressure with $16 \mathrm{~mm}$ pipe diameter. If lower irrigation intensity is required irrigation can be controlled by the change of pressure or decreased the operation time (on the concerned pressure). The peach has got a large water requirement on its yield production stage, therefore it is necessary to spread at least $10 \mathrm{~mm}$ plus water, exceeding the planed irrigation requirements in the last irrigation turn.

The micro sprinkler systems could avoid orchards from frost damages. For frost protection irrigation the micro sprinkler systems requires LDPE lateral tubes with 20 and 25 $\mathrm{mm}$ diameter and low-intensity, fogging, pulverizing sprinklers have to be placed $4 \mathrm{~m}$ distance in the rows above the canopy. Frost irrigation depends on the risk of frost damage: 2$4 \mathrm{~mm}\left(20-40 \mathrm{~m}^{3} / \mathrm{ha} / \mathrm{hour}\right)$. This method could protect the trees form the frost up to $6-8{ }^{\circ} \mathrm{C}$. The sprinklers should start when the temperature is above the critical damage temperature (depending on the phonological phase) and stop the irrigation above $0^{\circ} \mathrm{C}$. The frost protection system is suitable for irrigation of an orchard or climate controlling as well.

\section{Acknowledgement}

This study is funded by TECH_08-A3/2-2008-0373 and TECH_08-A4/2-2008-0138 projects. 
Table 1. The irrigation requirement of Sweet Lady in the driest year

\begin{tabular}{|c|c|c|c|c|c|c|}
\hline Date & $\begin{array}{c}\text { Water depletion } \\
\%\end{array}$ & $\begin{array}{l}\text { Net irrigation } \\
(\mathrm{mm})\end{array}$ & $\begin{array}{l}\text { Gross irrigation } \\
(\mathrm{mm})\end{array}$ & $\begin{array}{l}\text { Flow* } \\
(1 / \mathrm{s} / \mathrm{ha})\end{array}$ & $\begin{array}{c}\text { Irrigation requirement } \\
\text { of a tree }(1 / \text { tree } / \mathrm{h})\end{array}$ & $\begin{array}{l}\text { Operation time } \\
\text { (hour) }\end{array}$ \\
\hline \multicolumn{7}{|c|}{ Bare soil } \\
\hline 8 May & 31 & 54,2 & 57,0 & 0,82 & 3,54 & 10,6 \\
\hline 12 June & 32 & 62,9 & 66,2 & 0,22 & 0,95 & 2,9 \\
\hline 27 June & 32 & 65,9 & 69,4 & 0,54 & 2,33 & 7,0 \\
\hline 13 July & 30 & 62,7 & 66,0 & 0,48 & 2,07 & 6,2 \\
\hline 5 August & 32 & 66,0 & 69,4 & 0,35 & 1,51 & 4,5 \\
\hline 19 August & 32 & 67,1 & 70,7 & 0,58 & 2,51 & 7,5 \\
\hline 12 September & 2 & & & & & \\
\hline \multicolumn{7}{|c|}{ Active ground cover } \\
\hline 7 May & 30 & 53,4 & 56,2 & 0,93 & 4,02 & 12,1 \\
\hline 8 June & 31 & 60,8 & 64 & 0,23 & 0,99 & 3,0 \\
\hline 20 June & 31 & 62,5 & 65,8 & 0,63 & 2,72 & 8,2 \\
\hline 30 June & 31 & 65,7 & 69,1 & 0,80 & 3,46 & 10,4 \\
\hline 13 July & 31 & 65,4 & 68,8 & 0,61 & 2,64 & 7,9 \\
\hline 30 July & 30 & 63,0 & 66,3 & 0,45 & 1,94 & 5,8 \\
\hline 10 August & 33 & 68,8 & 72,4 & 0,76 & 3,28 & 9,8 \\
\hline 21 August & 31 & 63,8 & 67,1 & 0,71 & 3,07 & 9,2 \\
\hline 12 September & 8 & & & & & \\
\hline
\end{tabular}

*The Flow represents the continuous water discharge needed to satisfy crop irrigation requirements over the irrigation interval period

\section{References}

Allen, R.G., Pereira, L.S., Raes, D., Smith, M. (1998): Crop evapotranspiration: Guidelines for computing crop requirements. Irrigation and Drainage Paper No. 56, FAO, Rome, Italy, 300.

Ayars, J. E., Johnson, Ć. R. S., Phene, Ć. C. J., Trout, T. J., Clark, D. A. and Mead, Ć. R. M. (2003): Water use by dripirrigated late-season peaches. Irrig Sci, 22: 187-194

Black, B.L., R. Hill and G. Cardon. (2008): Orchard Irrigation: Peach. Utah State University. 1-4.

Papp J. (2003): Gyümölcstermesztési alapismeretek. Mezőgazda Kiadó, Budapest
Somlyódy, L. (2000): Strategy of Hungarian water management (In Hungarian). MTA Vízgazdálkodási Tudományos Kutatócsoportja, Budapest, 370.

Tóth, Á. (1995): Az esőszerü és mikroöntözés gyakorlata. KITE RT. Nádudvar

Várallyay, Gy. (2002): The role of soil and soil management in drought mitigation . In: Proc. Int. Conf. On Drought Mitigation and Prevention of Land Desertification, Bled, Slovenia, April 21-25. 2002. ICID-CIIC. (CD)

Várallyay, Gy. (2005): Klímaváltozások lehetséges talajtani hatásai a Kisalföldön. "Agro-21" Füzetek, Klímaváltozás - hatások - válaszok. 43: 11-23. 